\title{
Analysis of Crude Oil Production in Nigeria by Servicing Companies
}

\author{
${ }^{1 *}$ Oladimeji O.A., ${ }^{2}$ Ikotun D.O., ${ }^{3}$ Ademuyiwa J.A. and ${ }^{4}$ Olaniyan J.O \\ Department of Statistics, The Federal Polytechnic, Ile-Oluji, Nigeria
}

\begin{abstract}
The petroleum industry in Nigeria has brought unprecedented changes to the Nigerian economy, particularly in the past five decades when it replaced agriculture as the cornerstone of the Nigeria economy. The oil industry has risen to the commanding heights of the Nigerian economy, contributing the lion share to gross domestic product and accounting for the bulk of federal government revenue and foreign exchange earnings since early 1970. However, Nigeria's considerable endowment in fossil fuel has not translated into an enviable economic performance; rather, the nation's mono-cultural has assumed a precarious dimension in the past decades susceptible to the vagaries of the international oil markets. Empirical analysis was conducted by applying the Multiple Linear Regression of the Ordinary least square techniques, the joint distribution of independent variable contribute to the success of the total production prob(F. Statistic) $=0.00122$ which is less than 0.05 thereby establishing the significance of the independent variable. Conclusively, the Servicing Company relationship is not the same, also from estimated regression line only $\mathbf{x}_{2}$ (Joint Ventures AF/CARRY and $\mathbf{x}_{5}$ (Sole Risk Independent Companies) has the highest coefficient which implies that they have greater contribution to the total production. Keywords:Crude Oil, Foreign Exchange Earnings, Multiple Linear Regression, Servicing Company, Total Production.

DOI: $10.7176 / \mathrm{JETP} / 12-1-02$

Publication date: January $31^{\text {st }} 2022$
\end{abstract}

\section{INTRODUCTION}

Oil is a major source of energy in Nigeria and the world in general. Oil being the mainstay of the Nigerian economy plays a vital role in shaping the economic and political destiny of the country. Although Nigeria's oil industry was founded at the beginning of the century, it was not until the end of the Nigeria civil war (1967 - 1970) that the oil industry began to play a prominent role in the economic life of the country. Nigeria can be categorized as a country that is primarily rural, which depends on primary product exports (especially oil products). Since the attainment of independence in 1960 it has experienced ethnic, regional and religious tensions, magnified by the significant disparities in economic, educational and environmental development in the south and the north. These could be partly attributed to the major discovery of oil in the country which affects and is affected by economic and social components. Crude oil discovery has had certain impacts on the Nigeria economy both positively and adversely. On the negative side, this can be considered with respect to the surrounding communities within which the oil wells are exploited. Some of these communities still suffer environmental degradation, which leads to deprivation of means of livelihood and other economic and social factors. Although large proceeds are obtained from the domestic sales and export of petroleum products, its effect on the growth of the Nigerian economy as regards returns and productivity is still questionable, hence, the need to evaluate the relative impacts of crude oil on the economy. In the light of the study, the main objective is to assess the impact of crude oil on the Nigerian economy. Given the fact that the oil sector is a very crucial sector in the Nigeria economy, there is the dire need for an appropriate and desirable production and export policy for the sector. In Nigeria, though crude oil has contributed largely to the economy, the revenue has not been properly used. Considering the fact that there are other sectors in the economy, the excess revenue made from the oil sector can be invested in them to diversify and also increase the total GDP of the economy. This study comprises of five sections. Section two presents the background of the study, while the third section focuses on the research methodology. Section four includes data analysis and interpretation of results, and the final section presents and policy proposal and study conclusions.

Therefore, the purpose of this research work is to study the effect of the crude oil production in Nigeria by Servicing Companies for a period of ten years. And to deduce which of this crude oil produced in Nigeria by Servicing Companies between 2002 to 2011 has the highest production or consumption.

\subsection{HISTORICAL BACKGROUND OF OIL INDUSTRY IN NIGERIA}

Oil was discovered in Nigeria in 1956 at Oloibiri in the Niger Delta after half a century of exploration. The discovery was made by Shell-BP, at the time the sole concessionaire. Nigeria joined the ranks of oil producers in 1958 when its first oil field came on stream producing 5,100 bpd. After 1960, exploration rights in onshore and offshore areas adjoining the Niger Delta were extended to other foreign companies. In 1965 the EA field was discovered by Shell in shallow water southeast of Warri. In 1970, the end of the Biafran war coincided with the rise in the world oil price, and Nigeria was able to reap instant riches from its oil production. Nigeria joined the 
Organization of Petroleum Exporting Countries (OPEC) in 1971 and established the Nigerian National Petroleum Company (NNPC) in 1977; a state owned and controlled company which is a major player in both the upstream and downstream sectors [Blair 1976, pp. 98-120]. Following the discovery of crude oil by Shell D'Arcy Petroleum, pioneer production began in 1958 from the company's oil field in Oloibiri in the Eastern Niger Delta. By the late sixties and early seventies, Nigeria had attained a production level of over 2 million barrels of crude oil a day. Although production figures dropped in the eighties due to economic slump, 2004 saw a total rejuvenation of oil production to a record level of 2.5 million barrels per day. Current development strategies are aimed at increasing production to 4 million barrels per day by the year 2010. Petroleum production and export play a dominant role in Nigeria's economy and account for about $90 \%$ of her gross earnings. This dominant role has pushed agriculture, the traditional mainstay of the economy, from the early fifties and sixties, to the background.

While the discovery of oil in the eastern and mid-western regions of the Niger Delta pleased hopeful Nigerians, giving them an early indication soon after independent economic development was within reach, at the same time it signaled a danger of grave consequence: oil revenues fueled already existing ethnic and political tension and actually "burned" the country. This tension reached its peak with the civil war that lasted from 1967 to 1970 . As the war commenced, the literature reflected the hostility, the impact, and fate of the oil industry. Nigeria survived the war, and was able to recover mainly of the huge revenues from oil in the 1970s. For some three years an oil boom followed, and the country was awash with money. Indeed, there was money for virtually all the items in its developmental plan. The literature of the postwar years shifted to the analysis of the world oil boom and bust, collectively known as the "oil shock." Starting in 1973 the world experienced an oil shock that rippled through Nigeria until the mid - 1980s. This oil shock was initially positive for the country, but with mismanagement and military rule, it became all economic disaster. The larger middle class produced by the oil boom of the 1970s gradually became disenchanted in the 1980s, and rebellious in the 1990s. The enormous impact of the oil shock could not escape scholarly attention. For almost twenty years (1970s - 1990s), the virtual obsession was to analyze the consequences of oil on Nigeria, using different models and theories. A set of radical-oriented writers was concerned with the nationalization that took place during the oil shock as well as the linkages between oil and an activist foreign policy. Regarding the latter, the emphasis was on OPEC, Nigeria's strategic alliance formation within Africa, the vigorous efforts to establish the Economic Community of West African States (ECOWAS), and the country's attempts to use oil as a political weapon, especially in the liberation of South Africa from apartheid. If many had hoped that oil would turn Nigeria into an industrial power and a prosperous country based on a large middle class, they were to be disappointed when a formally rich country became a debtor nation by the 1980s. The suddenness of the economic difficulties of the 1980s "bust years" had an adverse effect on class relations and the oil workers who understood the dynamics of the industry. As if to capture the labor crisis, writings on oil workers during this period covered many interrelated issues, notably working conditions, strikes, and state labor relations. To be sure, labor issues were not new in the $1980 \mathrm{~s}$, since the left-oriented scholars had made a point of exposing labor relations in the colonial era. What was new after 1980 was the focus on oilworkers, unions, and class conflict [OPEC annual report 1983].

\subsection{LITERATURE REVIEW}

Etiebet (1999) observed that price of oilproducts is derived from crude oil prices and it therefore follows that prices of petroleum products should trail crude oil prices. According to the author, it is not always the case for a number of reasons. In the first place, there is always a time lag between crude oil processing and product distribution through network. Secondly, for socio-political reasons, government of both oil producing and consuming countries should invariably intervene in the market to influence products price determination. But in the actual fact, the extent of intervention depends on the specific needs of the country and the level of endowment of the products in question. The author noted that trailing oil products prices down crude oil prices has revealed that, crude oil cost is not the only cost incurred in supply and distribution of petroleum products. Other costs include refining, storing, transporting and distributing, the author asserted. Siddy (1999) asserted that the causes of price instability is attributed to scarcity caused by refinery maintenance and rehabilitation problem, low capacity utilization, supply, and demand inequality. The political change that Nigeria went through, which turned over the administration and endured a lingering economic down turn is enough reason to cause price instability of oil products in Nigeria. The author opined that trailing oil products prices down to crude oil prices has revealed that the instability in the prices of oil products was due to cost of refining, storing, transporting distributing and inefficiencies in the process. Dan (1999) asserted that Nigeria has four refineries, one of which is at Kaduna, Warri and two at Port-Harcourt with a total nominal refining capacity of 445,000 barrels per day.

The author noted that although the refineries find it very difficult to reach that $(445,000)$ due to frequent breakdown and operating problems such as vandalisation, which has been reduced and that more products are being pumped throughout the pipelines. Mbendi (2000) argued that in theory, Nigeria's refineries capacity is sufficient to meet its domestic consumption requirement. In practice, however, according to the author, the country has experienced frequent shortage of refined products since it refineries have poor configuration and operation 
inefficiency. The author stated that it has been estimated that smuggling amounts to over 320,000 barrels per day largely to Benin Republic, Niger, Chad, and Cameroon. The author noted that Nigeria has become a large importer of light petroleum products, importing thousands of tons of refined products. Runl (2010) asserted that people say Nigeria is dominated by oil and they are right because Nigeria seems to be exporting noting but oil. The government revenues are so dependent on oil, which has been managed quite protectively. But it's still extremely undesirable that internally generated revenue are such a small part of Nigeria's revenue because essentially, it means that all the revenues of the government is just coming down from heaven. It's like a gift and it is easy to waste a gift. The author noted that Nigeria is poor because of oil. Ewa and Agu (2003) shared their view that the dominance of petroleum in Nigerian economy has led to instability in the economy, which as a result makes price instability of oil products to be more prevalent in Nigeria than other countries. The author observed that smuggling is attractive and profitable due to price differential. This act of smuggling oil products from Nigeria to her neighbouring countries is one of the factors which made price instability of oil products to be prevalent. in Nigeria. In summary, the works reviewed are the work of many individuals who have shown concern in the area of this study. The most reoccurring term in the works reviewed were that price instability of oil products are prevalent due to ill-refinery maintenance, and rehabilitation problems, low capacity utilization, supply and demand inequality reduction in crude oil allocation, and smuggling of petroleum products.

Nigeria is an oil producing country which depend on it oil income for most of its federal revenue. The share reached $80 \%$ in 2008 (Central Bank of Nigeria 2011).

Christtos Trisimokos (2011) attempts to estimate the short - run and long- run price and income elasticities of crude oil demand in ten IEA member- countries. Specifically, the price and income elasticities for Sweden, Demark, Spain, Portugal, turkey, Finland, Italy, Germany, USA, and Japan are estimated. Crude oil consumption is a function of four explanatory variables real oil price, real GDP per capital, oil consumption lagged one year and a time trend represent Technological improvements.

\section{METHODOLOGY}

Econometric is the branch of economics discipline that brings to together economic theory, mathematics, statistic and computer science with economic phenomena with a view for making economic decision. The model and definition of variable is based on the production of crude oil and how it has been produced by regime and how it contributes to the economic growth of the country spanning between 2005 and 2015. The total production of crude oil [by Regime] can be expressed as a linear function as follow;

\section{$\boldsymbol{Y}=\boldsymbol{\beta}_{0}+\boldsymbol{\beta}_{1} \boldsymbol{x}_{1}+\boldsymbol{\beta}_{2} \boldsymbol{x}_{2}+\boldsymbol{\beta}_{3} \boldsymbol{x}_{3}+\boldsymbol{\beta}_{4} \boldsymbol{x}_{4}+\boldsymbol{\beta}_{5} \boldsymbol{x}_{5}+\boldsymbol{U}$}

Where $Y=$ total production of crude oil by Regime

$\mathbf{x}_{1}=$ the quantity of crude oil produced by joint ventures

$\mathbf{x}_{2}=$ the quantity of crude oil produce by venture AF/CARRY

$\mathbf{x}_{3}=$ the quantity of crude oil produced by Production Sharing Companies.

$\mathbf{x}_{4}=$ the quantity of crude oil produced by Service Contact Companies.

$\mathbf{x}_{5}=$ the quantity of crude oil produced by Sole Risk Independent Companies.
Test of significance: We use the test statistic
$\mathrm{t}=\frac{\beta-\beta}{S \cdot E(\beta)}$

Therefore, assuming normality homoscedasticity occur, the test statistic above has t-distribution with $\mathrm{n}$ - $\mathrm{k}$ degree of freedom.

Goodness of fit: The square of the correlation coefficient, $\mathrm{R}^{2}$ is called the coefficient of multiple determination or goodness of fit. $\quad \mathrm{R}^{2}=\frac{\sum \hat{Y}^{2}}{\sum Y^{2}}=\frac{S S R}{S S T}=\frac{E S S}{T S S} 1-\sum \frac{e 2}{Y 2}$

Hypothessis to be tested

$\mathrm{H}_{0}$ : there is no significant difference between $\mathrm{R}^{2}$ and zero

Symbolically $\quad \mathrm{H}_{0}: \mathrm{R}^{2}=0 \quad$ Versus

Versus $\quad \mathrm{H}_{1}: \mathrm{H}_{0}$ is not true

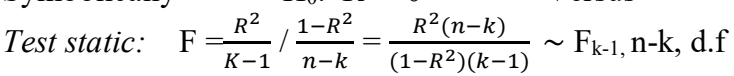

where $\mathrm{k}-1$ is the degree of freedom for estimated sum of squares and $\propto=$ level of significance

Decision: if $\mathrm{F}_{\text {cal }}>\mathrm{F}_{\text {tab }}$ rejecting $\mathrm{H}_{0}$ otherwise accept $\mathrm{H}_{0}$

Interpretation of $\mathrm{R}^{2}$ : The higher the value of $\mathrm{R}^{2}$, the greater the goodness of fit of the regression and If the null hypothesis, $\mathrm{H}_{0}$ is rejected at a particular level of significance then the value of $\mathrm{R}^{2}$ is significantly difference from zero.

The adjusted cofficient of determination $\left(\bar{R}^{2}\right)$ : In determination the adjusted, the adjusted $\left(\overline{R^{2}}\right)$, the coefficient of determine $\mathrm{R}^{2}$ which measures the proportion of the variation in the explanatory variables. $\quad \overline{\mathrm{R}}^{2}=\frac{E S S}{T S S}=$ $\mathrm{R}^{2}-\frac{(n-1)}{n-K}\left(1-\mathrm{R}^{2}\right)$

To test the overall significance of the parameter estimate $\beta \mathrm{i}$, we have an hypothesis which indicates. Ho: $\beta \mathrm{i}$ 's $=0 \forall \mathrm{I}$ Versus $\quad \mathrm{H}_{1}: \beta \mathrm{i} \neq 0 \forall \mathrm{I}$ 
Therefore the test statistic

$\mathrm{F}=\frac{R^{2} /(n-k)}{\left(1-R^{2}\right) /(k-1)} \sim \mathrm{f} \alpha, \mathrm{k}-1, \mathrm{n}-\mathrm{k}$

with $(\mathrm{K}-1),(\mathrm{n}-\mathrm{K})$ degree of freedom.

Autocorrelation : One of the assumptions of the linear regression model is that errors are independent, that is, error terms are pair wise uncorrelated. This claim was tested in the study as well as multicollinearity and heteroscedasticity as the case may be.

The examination of residuals: A residual $\varepsilon i$ is defined as the difference between the observed value and the fitted value, $\varepsilon i=\widehat{Y}_{l}-Y, \quad \mathrm{i}=1,2, \ldots \mathrm{n}$ where $\widehat{Y}=\mathrm{E}(\mathrm{Yi})$ The analysis of the residuals is an important technique for examining type of departure of the model from what is considered adequate.

\section{DATA ANALYSIS}

The time plot of all the variables that are of interest in the study is as depicted in figure 1. It shows that the $\mathbf{x}_{2}, \mathbf{x}_{3}$ and $\mathbf{x}_{5}$ have upward trend over period of interest in the study. This connotes that the three variables increases over the period. $\mathbf{x}_{2}$ has an erratic movement. It increases from the initial period (2005) up to 2015 and dropped from 2008 till 2010. In addition, it later maintained a steady increase from same 2008 throughout the period of study. $\mathbf{x}_{4}$ has downward trend between 2005 and 2006. It has an erratic movement between 2003 and 2005. It has steady downward trend i.e. dropped in 2005 till 2015 and. $\mathbf{x}_{1}$ has an increasing trend between 2005 and 2004 and fell sharply in 2005. It rose between 2005 and 2011, but before that, it maintained downward trend from 2008 throughout the period of study. Y behaviour is undulating with no particular pattern. However, it should be noted that it maintained its straight trend from its initial period till 2015. Joint Venture AF/CARRY

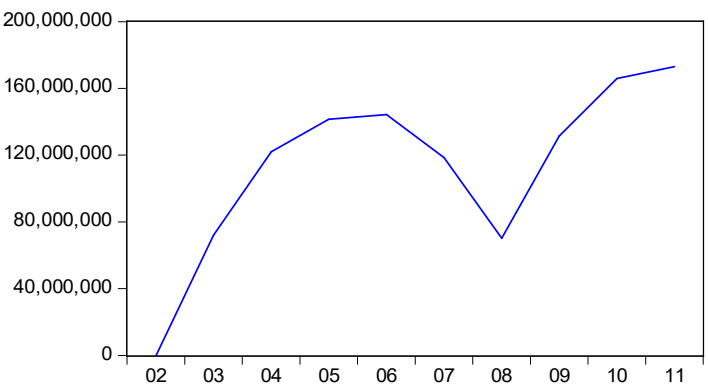

Production Sharing Companies

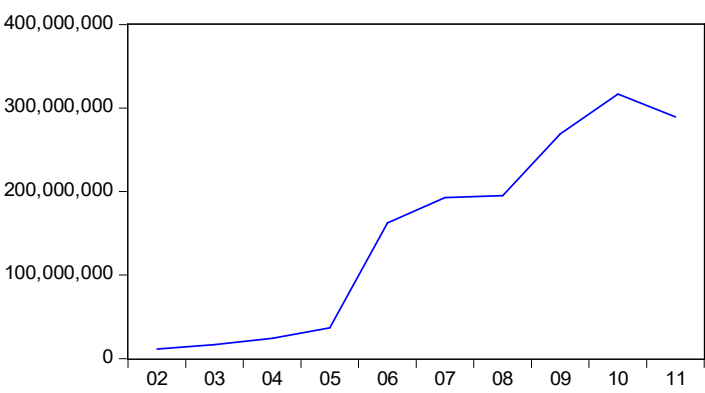

Sole RISK Independent Companies

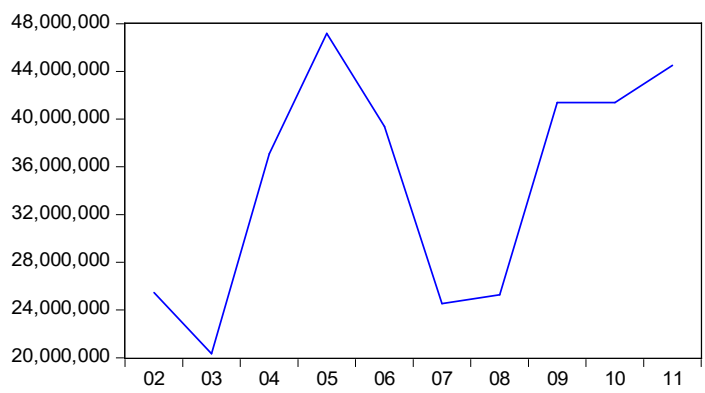

Joint Ventures

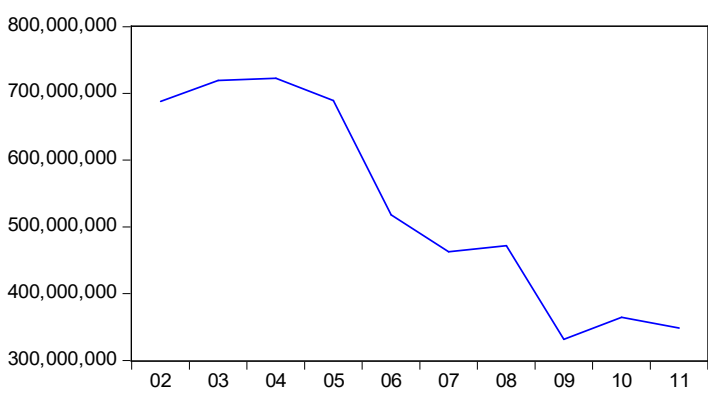

Service Contract Companies

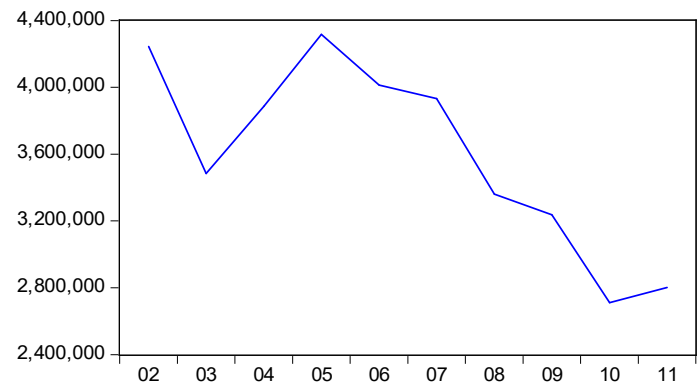

TOTAL

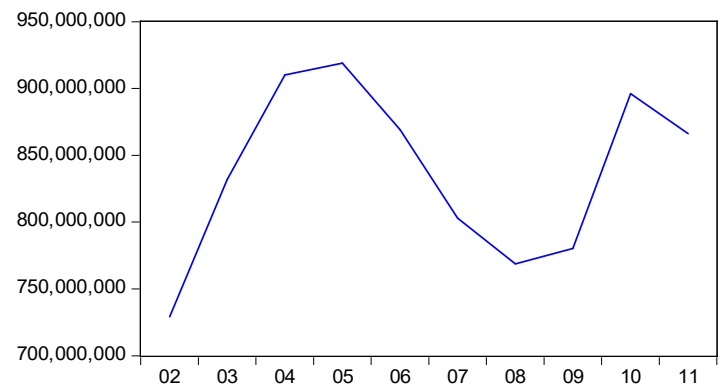

Figure 1: Time plot of variables of interest in the study 


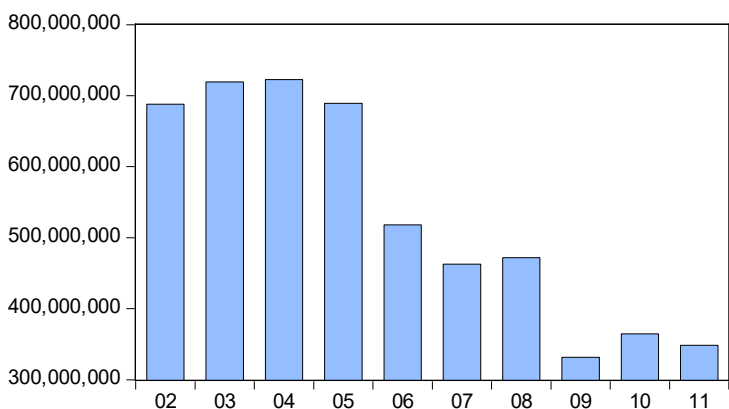

$\mathrm{X} 3$

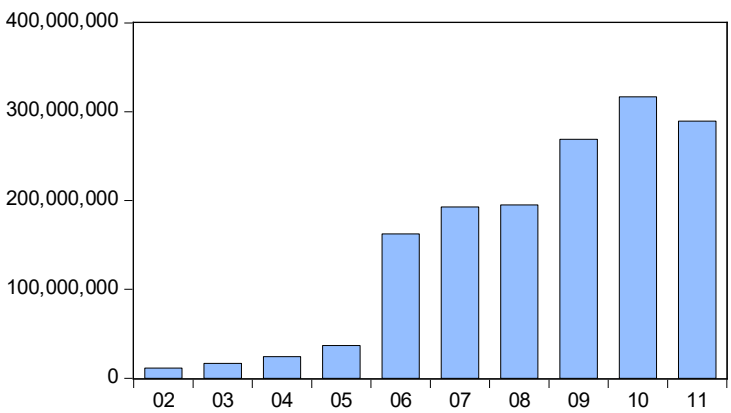

$\mathrm{X} 5$

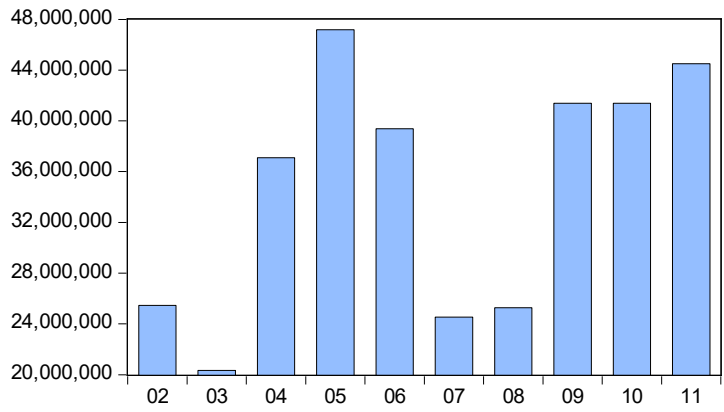

$\mathrm{X} 2$

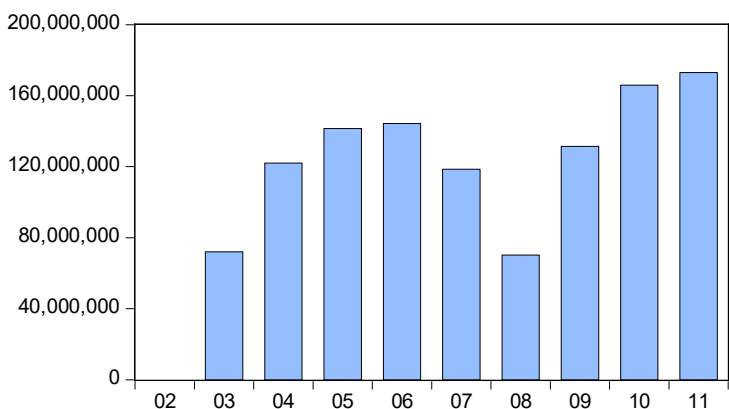

X4
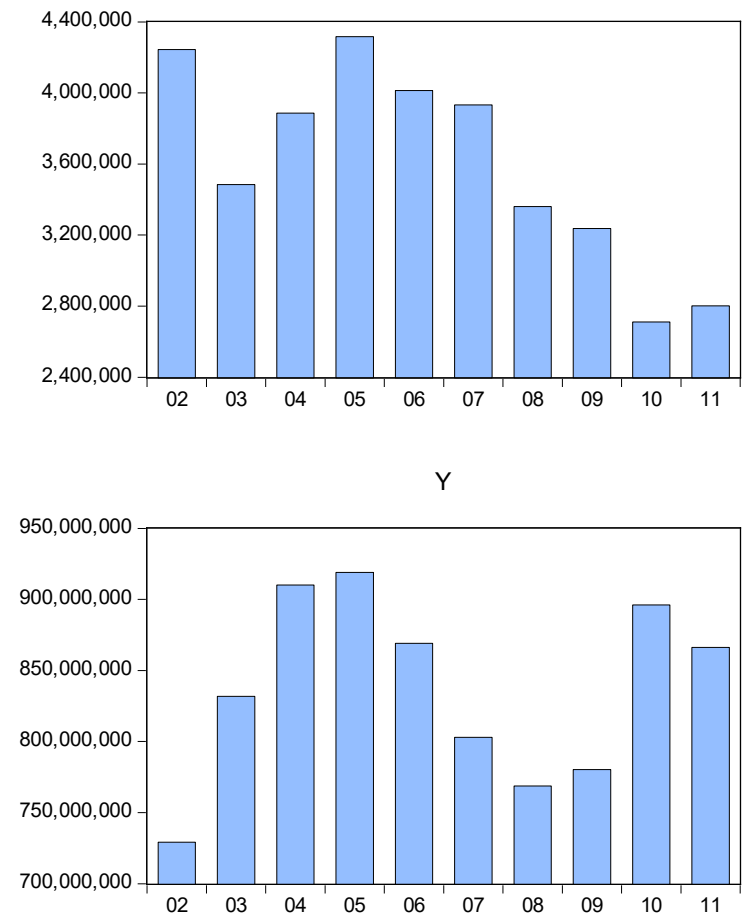

Figure 2: Bar chart of variables of interest in the study.

Table 1: Establishment of relationship between the total productions of crude oil in Nigeria and Servicing Companies

\section{Servicing companies}

Joint Ventures

Joint Ventures AF/CARRY

Production Sharing Companies

Service Contract Companies

Sole Risk Independent Companies

Paramete
Intercept
$807518998.6^{* * *}$
$732411684.3^{* * *}$
$837111357.9^{* * *}$
$856942733.2^{* * *}$
$686269405.2^{* * *}$

Paramet Total Production

0.056
$0.921 * *$
0.002
-5.454
$4.353 * *$

Diagnostics

\begin{tabular}{cc}
\multicolumn{2}{c}{ Diagnostics } \\
& F-statistic \\
0.018 & 0.145 \\
0.555 & $9.973 * *$ \\
0.000 & 0.000 \\
0.002 & 0.018 \\
0.427 & $5.971 * *$
\end{tabular}

$\mathbf{Y}=$ Total Production, $\mathbf{x}_{\mathbf{1}}=$ Joint Ventures, $\mathbf{x}_{\mathbf{2}}=$ Joint Ventures AF/CARRY, $\mathbf{x}_{\mathbf{3}}=$ Production Sharing Companies, $\mathbf{x}_{\mathbf{4}}=$ Service Contract Companies, $\mathbf{x}_{\mathbf{5}}=$ Sole Risk Independent Companies. From the empirical statistical point of view in the table1 and as F-statistics

(P-value) is < significant level we say it is significant and conclude that servicing companies (x's i.e joint ventures, AF/CARRY, Production Sharing Companies, Service Contract Companies and Sole Risk Independent Companies) jointly can influence the Total Production (Y).

Estimation of the parameters of the econometric model.

$\mathrm{E}(\mathrm{Y})=\mathrm{B}_{0}+\mathrm{B}_{1} \mathrm{X}_{1}+\mathrm{B}_{2} \mathrm{X}_{2}+\mathrm{B}_{3} \mathrm{X}_{3}+\mathrm{B}_{4} \mathrm{X}_{4}+\mathrm{B}_{5} \mathrm{X}_{5}$ 
$\mathrm{E}(\mathrm{Y})=19157697$

Testing the significance of regressors: From the establishment of the regression analysis table above it was discovered that among the servicing companies; it is only joint ventures AF/CARRY and sole risk independent companies the significant variables to explain the total production.

From appendix (vii)

Testing the significance of the complete regression anova table

$\mathrm{H}_{0}$ : servicing company relationship are the same Versus $\mathrm{H}_{1}$ : not $\mathrm{Ho}$ at $\alpha=0.05$

since the overall Prob (F-statistics) is lesser than 0.05 , we say the result is significant and reject $\mathrm{H}_{0}$ and conclude that servicing company relationship are not the same.

From appendix (viii

Testing residuals and the autocorrelation with decision

Hypothesis testing

$\mathrm{H}_{0}$ : residuals are not auto correlated versus $\quad \mathrm{H}_{1}$ : residuals are auto correlated at $\alpha=0.05$

Decision rule: reject $\mathrm{H}_{0}$ if $\mathrm{p}$-value is greater than 0.05 , otherwise accept $\mathrm{H}_{0}$

From appendix (ix) based Autocorrelation result

The Breusch-Godfrey Serial Correlation LM Test result above indicates that residuals in the model are autocorrelated as the null hypothesis will be rejected since the test is significant. And the Chi square value $<0.05$ and meaning that the result is significant.

From appendix (x)

Test of heteroscedasticity, hypothesis testing, test statistics and decision.

Hypothesis testing

$\mathrm{H}_{0}$ : residuals are not heteroscadastic (homoscedastic) versus $\mathrm{H}_{1}$ : not $\mathrm{Ho}$ at $\alpha=0.05$

Decision rule: reject $\mathrm{H}_{0}$ if $\mathrm{p}$-value is greater than 0.05 , otherwise accept $\mathrm{H}_{0}$

Choosing the obs. R-squared (test stat. $=6.6667$ ) and its corresponding prob. Chi-squared $(5)=0.2466$ from the Heteroskedasticity Test: Breusch-Pagan-Godfrey above. The result shows that residuals in the model are not heteroscadastic i.e homoscedastic since its p-value $(0.2466)>0.05$. Meaning that the model is insignificant and null hypothesis will not be rejected.

\section{SUMMARY, CONCLUSION and RECOMMENDATION}

This project critically examined the strength of relationship between the total production of crude oil in Nigeria and Servicing Companies (that are producing crude oil per regime). The table in appendix (I) indicates that both $\mathbf{x}_{2}$ and $\mathbf{x}_{5}$ have significant relationship on the production of crude oil while others do not. The coefficient interpretation goes thus that joint ventures have a very less significantly relationship with Total Production and positive relationship exist between them which mean that a unit increase of joint ventures will increases total production by $5 \%$ provided others independent variables are kept constant. Also, total production will increase by $92 \%$ given a $100 \%$ increase in joint ventures AF/CARRY while other factors are fixed. More so, a unit increase in Production Sharing Company positively increases total production by $0.2 \%$ provided that all other variable are kept constant. However, total production will fall or decrease by $54 \%$ for an additional $100 \%$ increase of service contract companies and lastly, one unit increase in sole risk independent companies is an increase in total production by $43.5 \%$ unit holding other independent variable fixed.

Model R squared (0.983853). 98\% variation of total production can be explained the five independent variable. i.e joint ventures, joint venture AF/CARRY, production sharing companies, service contract companies and sole risk independently companies can influence only $98.39 \%$ on total company. More so, the $\mathrm{R}^{2}$ indicates that the model is of good fit or nicely fitted or validity and reliably.

\subsection{CONCLUSION}

It is apparent from the empirical analysis in chapter four that fitting econometric model is appropriate in establishing the functional relationship that exists between the total production of crude oil and the explanatory variables.

The estimated regression model is given below:

$\mathrm{E}(\mathrm{Y})=19157697+0.950334 \mathrm{X}_{1}+0.993823 \mathrm{X}_{2}+0.946222 \mathrm{X}_{3}+7.035322 \mathrm{X}_{4}+0.798971 \mathrm{X}_{5}$

However, it is on this basis that the following conclusions were made

- It shows from estimated regression line that the variable $\mathbf{x}_{\mathbf{2}}$ and $\mathbf{x}_{\mathbf{5}}$ has the highest coefficient which implies that they have greater contribution to the response variable $\mathbf{Y}$ (Total production of crude oil.

- $\quad$ The coefficient of determination $\left(R^{2}=0.983853\right)$ is found to be statistical significant.

- The nature of the data almost follows the ordinary least squares assumptions because there is not heteroscedasticity. 


\subsection{RECOMMENDATION}

The joint distribution of independent variable contribute to the success of the total production prob(F.Statistic) $=$ 0.00122 which is less than 0.05 , so we now recommend that the oil production companies should proceed in their production and recruit more expert in order to enhance their production and create necessary facilities that necessitate successful production of oil in Nigeria. Federal government should assist the oil company by funding the major body of oil production at the right time as well as reducing tax rate of the company that are also working under NNPC.

\section{REFERENCE}

Obadan M.I (1987) the impact of petroleum on the Nigeria Economy. Central Bank of Nigeria (2003): Annual Report and Statement of Account, Vol.12, CBN Publications. Central Bank of Nigeria (2005):Economic and Financial Review, Vol.14, CBN Publications.

Ene, Ebele. "Oil and the Environment in Nigeria: the Shape of an Environment Policy" in the OPEC Bulletin (Vol. 25), 1994.

Europa. The Europa World Year Book 1997 (Vol. II). Europa Publications Ltd., 1997.

Forrest, Tom. Politics and Economics in Nigeria. Oxford: Westview Press, 1993.

Fyrnas, Jedrzej George. "Political Instability and Business: Focus on Shell” in Third World Quarterly (Vol.19 no.3) 1998.

Human Rights Watch, The Price of Oil: Corporate Responsibility and Human Rights Violations in Nigeria's Oil Producing Communities. New York: Human Rights Watch, 1999.

Omoweh, Daniel. "Shell and Land Crisis in Rural Nigeria: A Case Study of the Isoko Oil Areas" in the Scandinavian Journal of Development Alternatives and Area Studies (Vol. 17), 1998. p.20.

Omoweh, Daniel. "Shell, Environmental Pollution, and Health in Nigeria" in Afrika Spectrum (vol.30). 1995.

Okonmah, Patrick. "The Right to A Clean Environment: the Case for the Peoples of Oil Producing Communities in the Nigerian Delta" in the Journal of African Law. Oxford: Oxford University Press, 1997.

Odularu, .G.O (2008), "Crude oil and Nigerian Economic Performance".

Odularu, .G.O., C. Okonkwo, (2009), "Does Energy Consumption Contribute to the Economic Performance?" Empirical Evidence from Nigeria.

Helleiner G.K (1964) peasant agriculture, crude oil government and economic growth in Nigeria.

NNPC Annual Reports (1978-1986). Nigeria National Petroleum Corp. Annual reports of the petroleum inspectorate.

Helleiner, G.K., 1964, the Fiscal Role of the Marketing Boards in Nigerian Economic Development, the Economic Journal, 74(295), 582-610

Frynas, J.G., 1993, Oil in Nigeria, LIT, Munich.Frynas 1993:16). In 1977, the company was amalgamated with the Ministry of Petroleum, and changed its name to the Nigerian National Petroleum Corporation (Oyrwole and Lucas 2000: 374). 


\section{APPENDIX (I)}

Dependent Variable: Y

Method: Least Squares

Date: 10/11/14 Time: 11:16

Sample: 20022011

Included observations: 10

\begin{tabular}{crccr}
\hline \hline \multicolumn{1}{c}{ Variable } & Coefficient & Std. Error & t-Statistic & Prob. \\
\hline \hline C & 19157697 & $2.06 \mathrm{E}+08$ & 0.092982 & 0.9304 \\
X1 & 0.950334 & 0.225717 & 4.210293 & 0.0136 \\
X2 & 0.993823 & 0.180784 & 5.497290 & 0.0053 \\
X3 & 0.946222 & 0.352672 & 2.683011 & 0.0551 \\
X4 & 7.035322 & 15.47833 & 0.454527 & 0.6730 \\
X5 & 0.798971 & 0.696225 & 1.147576 & 0.3151 \\
\hline \hline & 0.983853 & Mean dependent var & $8.37 \mathrm{E}+08$ \\
R-squared & 0.963668 & S.D. dependent var & 65082177 \\
Adjusted R-squared & 12405255 & Akaike info criterion & 35.78885 \\
S.E. of regression & $6.16 \mathrm{E}+14$ & Schwarz criterion & 35.97040 \\
Sum squared resid & -172.9442 & Hannan-Quinn criter. & 35.58969 \\
Log likelihood & 48.74334 & Durbin-Watson stat & 1.933953 \\
F-statistic & 0.001122 & & \\
Prob(F-statistic) & & & \\
\hline \hline
\end{tabular}

\section{Servicing companies}

Joint Ventures

Joint Ventures AF/CARRY

Production Sharing Companies

Service Contract Companies

Sole Risk Independent Companies

\section{Parameter Estimates} Intercept

$807518998.6 * * *$
$732411684.3 * * *$
$837111357.9 * * *$
$856942733.2 * * *$
$686269405.2 * * *$

\section{Total Production}

0.056
$0.921^{* *}$
0.002
-5.454
$4.353^{* *}$

Diagnostics R-square F-statistic

0.018

0.555

0.000

0.002

0.427
0.145

$9.973 * *$

0.000

0.018

$5.971 * *$ 


Regression $\begin{gathered}\text { Appendix (ii) } \\
\text { Model Summary }\end{gathered}$
\begin{tabular}{|l|r|r|r|r|r|}
\hline Model & R & \multicolumn{2}{|c|}{ R Square } & Adjusted R Square & Std. Error of the Estimate \\
\hline 1 & & $.134^{\mathrm{a}}$ & & .018 & \\
\hline
\end{tabular}

a. Predictors: (Constant), JOINT VENTURES

\section{ANOVA ${ }^{\mathrm{a}}$}

\begin{tabular}{|c|c|c|c|c|c|c|}
\hline Model & & Sum of Squares & Df & Mean Square & $\mathrm{F}$ & Sig. \\
\hline \multirow{3}{*}{1} & Regression & 680418440550422.500 & 1 & 680418440550422.500 & .145 & $.713^{\mathrm{b}}$ \\
\hline & Residual & 37440789527505352.000 & 8 & 4680098690938169.000 & & \\
\hline & Total & 38121207968055776.000 & 9 & & & \\
\hline
\end{tabular}

a. Dependent Variable: TOTAL

b. Predictors: (Constant), JOINT VENTURES

Coefficients $^{\mathbf{a}}$

\begin{tabular}{|c|c|c|c|c|c|c|}
\hline \multirow{2}{*}{\multicolumn{2}{|c|}{ Model }} & \multicolumn{2}{|c|}{ Unstandardized Coefficients } & \multirow{2}{*}{$\begin{array}{c}\text { Standardized } \\
\text { Coefficients } \\
\text { Beta }\end{array}$} & \multirow[t]{2}{*}{$\mathrm{T}$} & \multirow[t]{2}{*}{ Sig. } \\
\hline & & $\mathrm{B}$ & Std. Error & & & \\
\hline & (Constant) & 807518998.647 & 81214860.664 & & 9.943 & .000 \\
\hline 1 & JOINT VENTURES & .056 & .146 & .134 & .381 & .713 \\
\hline
\end{tabular}

a. Dependent Variable: TOTAL

\section{Regression}

\section{Model Summary}

\begin{tabular}{|l|r|r|r|c|}
\hline Model & \multicolumn{1}{|c|}{$\mathrm{R}$} & $\mathrm{R}$ Square & \multicolumn{1}{|c|}{$\begin{array}{c}\text { Adjusted R } \\
\text { Square }\end{array}$} & $\begin{array}{c}\text { Std. Error of the } \\
\text { Estimate }\end{array}$ \\
\hline 1 & $.745^{\mathrm{a}}$ & .555 & .499 & 46054677.105 \\
\hline
\end{tabular}

a. Predictors: (Constant), AF/CARRY

ANOVA ${ }^{\mathrm{a}}$

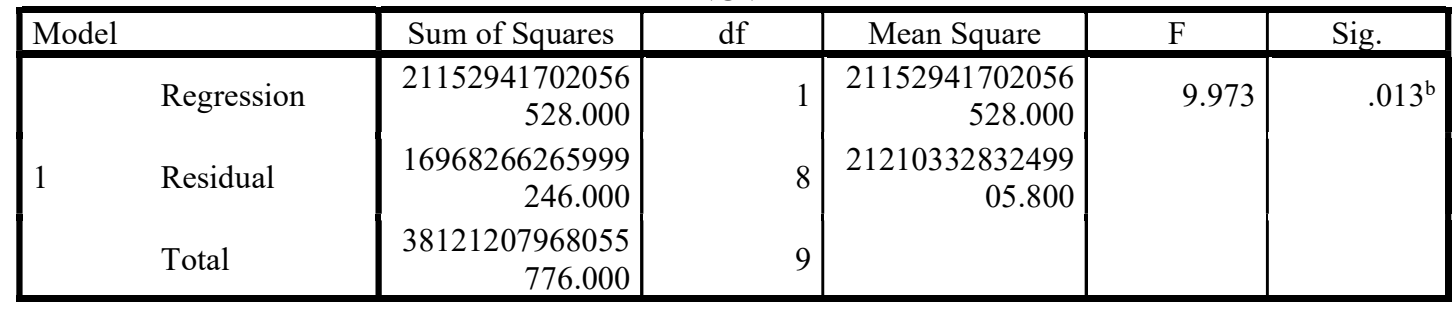

a. Dependent Variable: TOTAL

b. Predictors: (Constant), AF/CARRY

\section{Coefficients $^{\mathrm{a}}$}

\begin{tabular}{|c|c|c|c|c|c|}
\hline \multirow[t]{2}{*}{ Model } & \multicolumn{2}{|c|}{ Unstandardized Coefficients } & & \multirow[t]{2}{*}{$\mathrm{t}$} & \multirow[t]{2}{*}{ Sig. } \\
\hline & B & Std. Error & Beta & & \\
\hline $\begin{array}{ll}1 & \text { (Constant) } \\
1 & \text { AF/CARRY }\end{array}$ & $\begin{array}{r}732411684.329 \\
921\end{array}$ & $\begin{array}{r}36285707.701 \\
292\end{array}$ & .74 & $\begin{array}{r}20.185 \\
3.158\end{array}$ & $\begin{array}{l}.000 \\
013\end{array}$ \\
\hline
\end{tabular}

a. Dependent Variable: TOTAL 


\section{Regression}

Model Summary

\begin{tabular}{|l|r|r|r|r|}
\hline Model & \multicolumn{1}{|c|}{$\mathrm{R}$} & R Square & \multicolumn{1}{c|}{$\begin{array}{c}\text { Adjusted R } \\
\text { Square }\end{array}$} & $\begin{array}{c}\text { Std. Error of the } \\
\text { Estimate }\end{array}$ \\
\hline 1 & $.003^{\mathrm{a}}$ & .000 & -.125 & 69029735.606 \\
\hline
\end{tabular}

a. Predictors: (Constant), PROD. SHARING COMPANIES

ANOVA $^{\mathrm{a}}$

\begin{tabular}{|c|c|c|c|c|c|c|}
\hline Model & & Sum of Squares & Df & Mean Square & $\mathrm{F}$ & Sig. \\
\hline & Regression & $\begin{array}{r}372785275734.12 \\
5\end{array}$ & 1 & $\begin{array}{r}372785275734.12 \\
5\end{array}$ & \multirow[t]{3}{*}{.000} & \multirow[t]{3}{*}{$.993^{\mathrm{b}}$} \\
\hline 1 & Residual & $\begin{array}{r}38120835182780 \\
040.000\end{array}$ & 8 & $\begin{array}{r}47651043978475 \\
05.000\end{array}$ & & \\
\hline & Total & $\begin{array}{r}38121207968055 \\
776.000\end{array}$ & 9 & & & \\
\hline
\end{tabular}

a. Dependent Variable: TOTAL

b. Predictors: (Constant), PROD. SHARING COMPANIES

Coefficients $^{\mathbf{a}}$

\begin{tabular}{|c|c|c|c|c|c|c|}
\hline \multirow{2}{*}{\multicolumn{2}{|c|}{ Model }} & \multicolumn{2}{|c|}{ Unstandardized Coefficients } & \multirow{2}{*}{$\begin{array}{c}\begin{array}{c}\text { Standardized } \\
\text { Coefficients }\end{array} \\
\text { Beta }\end{array}$} & \multirow[t]{2}{*}{$\mathrm{t}$} & \multirow[t]{2}{*}{ Sig. } \\
\hline & & B & Std. Error & & & \\
\hline & (Constant) & 837111357.869 & 36214404.862 & & 23.115 & .000 \\
\hline 1 & $\begin{array}{l}\text { PROD. SHARING } \\
\text { COMPANIES }\end{array}$ & .002 & .191 & .003 & .009 & .993 \\
\hline
\end{tabular}

a. Dependent Variable: TOTAL

\section{Regression}

Model Summary

\begin{tabular}{|l|r|r|r|c|}
\hline Model & \multicolumn{1}{|c|}{$\mathrm{R}$} & R Square & \multicolumn{1}{|c|}{$\begin{array}{c}\text { Adjusted R } \\
\text { Square }\end{array}$} & $\begin{array}{c}\text { Std. Error of the } \\
\text { Estimate }\end{array}$ \\
\hline 1 & $.047^{\mathrm{a}}$ & .002 & -.123 & 68954551.606 \\
\hline
\end{tabular}

a. Predictors: (Constant), SERVICE CONTRACT COMPANIES

ANOVA $^{\mathrm{a}}$

\begin{tabular}{|c|c|c|c|c|c|c|}
\hline Model & & Sum of Squares & $\mathrm{df}$ & Mean Square & $\mathrm{F}$ & Sig. \\
\hline & Regression & $\begin{array}{r}83366470713763 . \\
950\end{array}$ & 1 & $\begin{array}{r}83366470713763 . \\
950\end{array}$ & \multirow[t]{3}{*}{.018} & \multirow[t]{3}{*}{$.898^{\mathrm{b}}$} \\
\hline 1 & Residual & $\begin{array}{r}38037841497342 \\
016.000\end{array}$ & 8 & $\begin{array}{r}47547301871677 \\
52.000\end{array}$ & & \\
\hline & Total & $\begin{array}{r}38121207968055 \\
776.000 \\
\end{array}$ & 9 & & & \\
\hline
\end{tabular}

a. Dependent Variable: TOTAL

b. Predictors: (Constant), SERVICE CONTRACT COMPANIES

Coefficients $^{\mathrm{a}}$

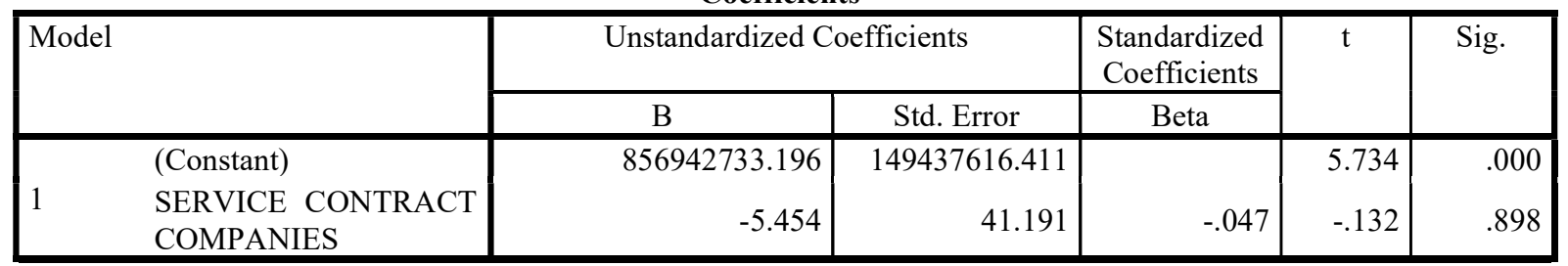

a. Dependent Variable: TOTAL 


\section{Regression}

Model Summary

\begin{tabular}{|l|r|r|r|r|}
\hline Model & \multicolumn{1}{|c|}{$\mathrm{R}$} & R Square & \multicolumn{1}{c|}{$\begin{array}{c}\text { Adjusted R } \\
\text { Square }\end{array}$} & $\begin{array}{c}\text { Std. Error of the } \\
\text { Estimate }\end{array}$ \\
\hline 1 & $.654^{\mathrm{a}}$ & .427 & .356 & 52235717.324 \\
\hline
\end{tabular}

a. Predictors: (Constant), SOLE RISK IND. COMPANIES

ANOVA ${ }^{a}$

\begin{tabular}{|c|c|c|c|c|c|c|}
\hline Model & & Sum of Squares & df & Mean Square & $\mathrm{F}$ & Sig. \\
\hline & Regression & $\begin{array}{r}16292646653564 \\
018.000\end{array}$ & 1 & $\begin{array}{r}16292646653564 \\
018.000\end{array}$ & 5.971 & $.040^{\mathrm{b}}$ \\
\hline 1 & Residual & $\begin{array}{r}21828561314491 \\
756.000\end{array}$ & 8 & $\begin{array}{r}27285701643114 \\
69.500\end{array}$ & & \\
\hline & Total & $\begin{array}{r}38121207968055 \\
776.000\end{array}$ & 9 & & & \\
\hline
\end{tabular}

a. Dependent Variable: TOTAL

b. Predictors: (Constant), SOLE RISK IND. COMPANIES

Coefficients $^{\mathbf{a}}$

\begin{tabular}{|c|c|c|c|c|c|c|c|}
\hline \multirow[t]{2}{*}{ Model } & & & \multicolumn{2}{|c|}{$\begin{array}{l}\text { Unstandardized } \\
\text { Coefficients }\end{array}$} & \multirow{2}{*}{$\begin{array}{c}\begin{array}{c}\text { Standardized } \\
\text { Coefficients }\end{array} \\
\text { Beta }\end{array}$} & \multirow[t]{2}{*}{$\mathrm{t}$} & \multirow[t]{2}{*}{ Sig. } \\
\hline & & & $\mathrm{B}$ & $\begin{array}{l}\text { Std. } \\
\text { Error }\end{array}$ & & & \\
\hline & (Constant) & & 686269405.245 & $\begin{array}{r}64002 \\
592.82\end{array}$ & & 10.723 & .000 \\
\hline & $\begin{array}{l}\text { SOLE RISK } \\
\text { COMPANIES }\end{array}$ & IND. & 4.353 & 1.781 & .654 & 2.444 & .040 \\
\hline
\end{tabular}

a. Dependent Variable: TOTAL

\section{Appendix (vii)}

Dependent Variable: Y

Method: Least Squares

Date: 10/11/14 Time: 11:16

Sample: 20022011

Included observations: 10

\begin{tabular}{crlll}
\hline \hline \multicolumn{1}{c}{ Variable } & Coefficient & Std. Error & t-Statistic & Prob. \\
\hline \hline C & 19157697 & $2.06 \mathrm{E}+08$ & 0.092982 & 0.9304 \\
X1 & 0.950334 & 0.225717 & 4.210293 & 0.0136 \\
X2 & 0.993823 & 0.180784 & 5.497290 & 0.0053 \\
X3 & 0.946222 & 0.352672 & 2.683011 & 0.0551 \\
X4 & 7.035322 & 15.47833 & 0.454527 & 0.6730 \\
X5 & 0.798971 & 0.696225 & 1.147576 & 0.3151 \\
\hline \hline & 0.983853 & Mean dependent var & $8.37 \mathrm{E}+08$ \\
R-squared & 0.963668 & S.D. dependent var & 65082177 \\
Adjusted R-squared & 12405255 & Akaike info criterion & 35.78885 \\
S.E. of regression & $6.16 \mathrm{E}+14$ & Schwarz criterion & 35.97040 \\
Sum squared resid & -172.9442 & Hannan-Quinn criter. & 35.58969 \\
Log likelihood & 48.74334 & Durbin-Watson stat & 1.933953 \\
F-statistic & 0.001122 & & \\
Prob(F-statistic) & \multicolumn{4}{l}{} \\
\hline \hline
\end{tabular}




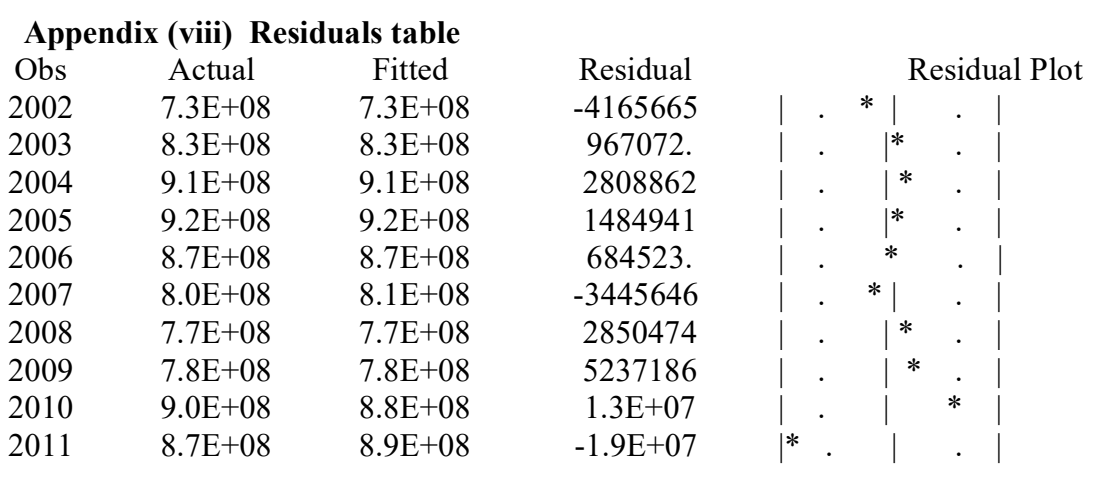

Appendix (ix) Auto correlation result Breusch-Godfrey Serial Correlation LM Test:

\begin{tabular}{llll}
\hline \hline F-statistic & 4.861121 & Prob. F(2,2) & 0.1706 \\
Obs*R-squared & 8.293842 & Prob. Chi-Square(2) & 0.0158 \\
\hline \hline
\end{tabular}

Test Equation:

Dependent Variable: RESID

Method: Least Squares

Date: 10/21/14 Time: 13:47

Sample: 20022011

Included observations: 10

Presample missing value lagged residuals set to zero.

\begin{tabular}{crlrr}
\hline \multicolumn{1}{c}{ Variable } & Coefficient & Std. Error & t-Statistic & Prob. \\
\hline C & $-1.57 \mathrm{E}+08$ & $1.55 \mathrm{E}+08$ & -1.014308 & 0.4172 \\
X1 & 0.166684 & 0.170197 & 0.979361 & 0.4307 \\
X2 & -0.065646 & 0.110131 & -0.596071 & 0.6116 \\
X3 & 0.281708 & 0.271260 & 1.038514 & 0.4081 \\
X4 & 3.183448 & 10.88803 & 0.292381 & 0.7975 \\
X5 & 0.759717 & 0.540765 & 1.404894 & 0.2952 \\
RESID(-1) & -2.330861 & 1.047272 & -2.225649 & 0.1560 \\
RESID(-2) & -1.095442 & 1.409639 & -0.777108 & 0.5184 \\
& & & & \\
\hline \hline R-squared & & & $2.41 \mathrm{E}-07$ \\
Adjusted R-squared & 0.829384 & Mean dependent var & 8270170. \\
S.E. of regression & 7246534 & S.D. dependent var & Akaike info criterion & 34.42051 \\
Sum squared resid & $1.05 \mathrm{E}+14$ & Schwarz criterion & 34.66258 \\
Log likelihood & -164.1025 & Hannan-Quinn criter. & 34.15496 \\
F-statistic & 1.388892 & Durbin-Watson stat & 2.538704 \\
Prob(F-statistic) & 0.480429 & & \\
\hline \hline
\end{tabular}


Appendix (x)

Heteroskedasticity Test: Breusch-Pagan-Godfrey

\begin{tabular}{llll}
\hline \hline F-statistic & 1.600067 & Prob. F(5,4) & 0.3347 \\
Obs*R-squared & 6.666760 & Prob. Chi-Square(5) & 0.2466 \\
Scaled explained SS & 1.833184 & Prob. Chi-Square(5) & 0.8717 \\
\hline \hline
\end{tabular}

Test Equation:

Dependent Variable: RESID^2

Method: Least Squares

Date: 10/21/14 Time: 14:09

Sample: 20022011

Included observations: 10

\begin{tabular}{crcrr}
\hline \hline \multicolumn{1}{c}{ Variable } & Coefficient & Std. Error & t-Statistic & Prob. \\
\hline \hline C & $-8.73 \mathrm{E}+14$ & $1.73 \mathrm{E}+15$ & -0.504592 & 0.6404 \\
X1 & 1522066. & 1895543. & 0.802971 & 0.4670 \\
X2 & -719661.0 & 1518205. & -0.474021 & 0.6602 \\
X3 & 2272979. & 2961696. & 0.767459 & 0.4856 \\
X4 & -86175750 & $1.30 \mathrm{E}+08$ & -0.662966 & 0.5436 \\
X5 & 4808340. & 5846812. & 0.822387 & 0.4571 \\
\hline \hline R-squared & 0.666676 & Mean dependent var & $6.16 \mathrm{E}+13$ \\
Adjusted R-squared & 0.250021 & S.D. dependent var & $1.20 \mathrm{E}+14$ \\
S.E. of regression & $1.04 \mathrm{E}+14$ & Akaike info criterion & 67.67583 \\
Sum squared resid & $4.34 \mathrm{E}+28$ & Schwarz criterion & 67.85738 \\
Log likelihood & -332.3791 & Hannan-Quinn criter. & 67.47667 \\
F-statistic & 1.600067 & Durbin-Watson stat & 1.887617 \\
Prob(F-statistic) & 0.334692 & & & \\
\hline \hline
\end{tabular}

